\title{
Bioengineering of Male Sterility in Rice (Oryza sativa L.)
}

\author{
Dung Nguyen Tien ${ }^{1}$, Moe Moe Oo ${ }^{1}$, Moon-Soo Soh $^{2}$, Soon Ki Park ${ }^{1}$ * \\ ${ }^{1}$ School of Applied Biosciences, Kyungpook National University, Daegu 702-701, Korea \\ ${ }^{2}$ Department of Molecular Biology, College of Life Science, Sejong University, Seoul 143-747, Korea
}

\begin{abstract}
Male sterility is an important trait for crop breeding program based on heterosis. Recent advances in molecular researches have led to the identification of genes involved in plant reproductive development and understanding the molecular functions of rice male gametophyte including roles of phytohormones in reproduction process. Here, we review the genes required for key aspects of anther/pollen development and conventional methods for the production of hybrid seeds in rice. Finally, we discuss the molecular approaches for the generation of male-sterile lines through the regulation of phytohormonal biosynthesis in reproductive organs.
\end{abstract}

Keywords Rice, Anther, Pollen, Male sterility, Hybrid rice, Phytohormones

\section{INTRODUCTION}

Sexual reproduction in higher organisms is an essential process for proliferation of genetically diverse individuals. After zygote formation, cell division and differentiation takes place to give rise to specialized tissues. In animals, cell determination is established at early stages of embryogenesis. However, in plants the fate of cells remained undetermined because meristematic tissues continually divide to form organs throughout the life cycle of plants. In addition, the life cycle of flowering plants alternates between the diploid sporophytic and haploid gametophytic generations. The tricellular pollen produced during male gametogenesis contains two sperm cells and one vegetative cell that are required for double fertilization of the egg cell and polar nuclei. The production of the male and female gametes is characterized by a series of complex events that make it a very attractive model for the study of cell polarity, cell specification, and cell to cell recognition (Borg et al. 2009). Many genes had been characterized involving male gamete formation in Arabidopsis thaliana, however only few studies were done on rice. Among the cereal crops, rice can be considered as the most attractive model for genome analysis since the completion of its genomic sequence. Moreover, rice has a small genome size and T-DNA insertions, cDNA libraries and ESTs are readily available. Microarray technology had been a powerful tool in producing high throughput data that includes profiling the expression of different genes at specific stages of reproductive development (Fujita et al. 2010; Deveshwar et al. 2011). Production of male sterile lines involves the use of the three-line and two-line system which utilizes the nuclearmitochondrial interaction and environmental condition, respectively (Virmani 1994; Virmani et al. 2003). However, the use of the three-line system is expensive and laborintensive. Furthermore, any changes in the environment can easily affect the sterility of plants in two-line system (Virmani et al. 2003). Surmounting these difficulties in breeding, the use of chemicals, specifically hormones could be of great help. Since the early 1970s, several potential chemical hybridizating agents (CHAs) for hybrid rice seed production were used, such as ethrel, RH-531 (Perez et al. 1973), sodium methyl arsenate (Chen et al. 1986) and sodium sulfate (Wang and Que 1981). However, the possible effect of CHAs on human health prompted its minimal use for hybrid production. Many research groups

Received September 17, 2013; Revised September 25, 2013; Accepted September 25, 2013; Published September 30, 2013

*Corresponding author Soon Ki Park, psk@knu.ac.kr, Tel: +82-53-950-7751, Fax: +82-53-958-6880 
have attempted to look for new and more efficient approaches in rice breeding. Studies on stamen development and discoveries of specific genes for anther or pollen development have been carried out (Ma 2005; Zhang and Wilson 2009; Cui et al. 2010; Nagato 2011). The role of major hormones in developing sexual organs and its biosynthesis pathway in plants were reported (Jacobsen et al. 1994; Itoh et al. 2001; Yang et al. 2009; Haga and Lino 2004; Plackett et al. 2011). Engineered male sterility has also been tackled in several researches (Khan 2005; Chase 2006). Here, we summarize the recent result of researches related to male sterility in rice.

\section{Stamen development in rice}

The flower structure of rice is relatively different from other cereal crops like wheat and maize. In rice, the inflorescence is characterized by the presence of one spikelet that contains one floret enclosed by a pair of empty glumes (Zhang and Wilson 2009). Furthermore, the rice floret is bisexual and the floral organs are asymmetrically arranged comprising of one lemma and one palea (first outer whorl), two lodicules (second whorl), six stamens (third whorl) and one pistil (fourth innermost whorl) (Zhang and Wilson 2009).

The course of male reproductive organ development in flowering plants begins with the establishment of the stamen (Ma 2005). The stamen consists of two distinct structures, the anther and the filament that is linked to four lobes by connective tissues. The anther is composed of highly specialized tissues for pollen generation while the filament provides support for the anther. The anther includes two thecae which are linked by connective tissue; each theca has two locules that are connected by septum and stomium (Matsui et al. 1999). Two sequential steps comprised the male gametophytic development, microsporogenesis and microgametogenesis. Itoh et al. (2005) classified anther development into eight stages, similar to Ikeda et al. (2004). Initially, the anther conformation changes from ovoidal into four-cornered shape and the archesporial cells (ACs) initiate at the hypodermal layer of the anther. The ACs differentiate into primary sporogenous cells (PSCs) and primary parietal cells (PPCs). After several rounds of division, anther wall layer is formed. PPCs will continue to divide periclinally to generate endothecium, a middle layer and a tapetum layer and will expand anticlinally. After the anther wall is completed, the pollen mother cells (PMCs) undergo meiosis to produce haploid gametes. Zhang and Wilson (2009) also classified the rice anther development into eight stages based on the morphological cellular landmark. However, with the results of light microscopy analysis of cellular changes occurring in anther rice, the anther developmental courses was categorized into 14 stages (Zhang and Wilson 2009; Zhang et al. 2011) similar to the Arabidopsis anther development (Sanders et al. 1999; Ma 2005). At stage 1, the floral meristem divided the cell in the L1, L2 and L3 layers, and then the anther primordium was formed. The anther primordia continue to undergo cell division until stage 5 . The characteristic anther structure was formed and developed with locule, wall, connective and vascular tissues in these stages. At stage 6 , the secondary sporogenous cells generate microspore mother cells (MMCs, also called PMCs) within the locule. From stage 7 to 9, PMCs underwent meiosis and formed dyads and tetrads of haploid microspore. From stage 9, free microspore was released from the tetrads with the degradation of callose wall. Early in this stage, microspores are spherical with thin exines (Li and Zhang 2010). The microspore vacuolates with an increase in volume forming roundshape at stage 10, and undergoes the first mitotic division with asymmetric cell division at stage 11. Subsequently, the generative cells separate from the pollen wall and move to the vegetative nucleus. At the end of stage 11, the tapetum cells almost completely degenerate into cellular debris and Ubisch bodies on the internal surface. At stage 12 , the generative cell in the microspore divided into two sperm cells and mature pollen formed with three nuclei. At stage 13, the lemma was opened and the anther dehiscence occurred. At stage 14, the anther continued the release of mature pollen grains. The genetic mechanism of stamen development is largely conserved between rice and model Eudicots (Yoshida and Nagato 2011). The ABC model was first established to explain the genetic mechanism of floral specification in Arabidopsis by Haughn and Somerville (1988). The sepals are solely characterized by the expression of A gene, while two classes of genes (A and B) worked together for the petals. The $\mathrm{B}$ and $\mathrm{C}$ genes are co-expressed 
for stamen specification. Only $\mathrm{C}$ gene acts for the carpels. The ABC model was further extended to the ABCDE or $\mathrm{ABCE}$ with $\mathrm{E}$ gene function encoded by sepallata (SEP) and $A G L 16$-like genes for development of all floral organs (Yoshida and Nagato 2011). Most of the ABCDE genes belong to MADS box family and are involved in floral development and evolution in higher plants (Causier et al. 2010).

In rice, at least five members of $S E P$-like genes were identified as OsMADS1, OsMADS5, OsMADS7, OsMADS8, and $O S M A D S 34$. Many research groups have insisted that OsMADS1 contributes to determining lemma and palea identity as well as meristem determinacy of inner floral organs. It is also one of the best characterized SEP-like genes (Jeon et al. 2000; Prasad et al. 2001; Agrawal et al. 2005; Chen et al. 2006). In another study, the knockdown of OsMADS1, OsMADS5, OsMADS7, and OsMADS8 causes homeotic transformation of all floral organs except the lemma into leaf-like organs (Cui et al. 2010). OsMADSI and OsMADS34 were also demonstrated to control inflorescence and spikelet development (Gao et al. 2010). OsMADS3 and OsMADS58 were identified to control stamen identity (Yamaguchi et al. 2006) and later on, regulate late anther development and pollen formation $(\mathrm{Hu}$ et al. 2011). During microgametogenesis, the pollen mother cell will produce haploid tetrad microspores. The microspore increases in size and undergoes an asymmetric cell division (Pollen mitosis I) which produces two cells, the vegetative cell and generative cell. The generative cell undergoes symmetric cell division to produce two sperm cells before pollen tube germination. Three-celled pollen (male gametophyte) is formed (Itoh et al. 2005; Borg et al. 2009). Microarray analysis of the four stages (pre-meiotic, meiotic, single-celled anther and trinucleate pollen) of anther development identified 1,000 genes specifically expressed in anther (Deveshwar et al. 2011). Among them, 82 were highly expressed pollen-specific genes (Jiang and Ramachandran 2010). By Affymetrix Gene Chip Rice Genome Array, Wei et al. (2010) found 25,062 pollenpreferential transcripts, among which 2,203 were development stage-enriched in rice. In a similar study, the stages of rice reproductive development were dissected and the gene expression levels were determined using microarray technology (Fujita et al. 2010). A total of 2,593 probe sets were identified on developing anther whereas only few were detected in other reproductive stages like fertilization and embryonic stages. Thus, the transcriptome of rice anther is distinctive and unique compared with other tissues/stages. Two anther-specific genes, LOC_Os04g08280/ Os04g0165000 and LOC_Os06g12320/Os06g0228500, were expressed specifically at meiotic stage of anther development. A decreased in the number of genes expressed in the mature pollen stage compared with other stages was also reported (Honys and Twell 2004). This is a common feature of higher plants which is also true in maize and Arabidopsis. In another study by Tsuchiya et al. (1992), Osc6 and Osc4 genes were identified to be specifically expressed in the tapetum in early microspore stage. The role of the tapetum is to provide proteins essential for the development of the microspore (Tsuchiya et al. 1994). Osc6 was found to encode LTP protein, which is required for post-meiotic anther development in rice (Zhang et al. 2010). Tapetum-specific promoters can be used to generate male sterile plants, a useful tool in hybrid breeding.

\section{Hormonal biosynthesis and metabolism}

Gibberellic acid (GA) is a very important phytohormone which regulates different aspects of plant development that includes embryo development, stem elongation and flower development particularly in anthers. GA-deficient mutants were observed to have abnormal anther developments which led to male sterility. In addition, several studies have proven that addition of GA to these mutants can restore fertility. Therefore GA offers enormous opportunities and possibilities through the manipulation of sterility/fertility especially in rice where it would significantly reduce labor and in the same way, increase accuracy of producing male sterile lines. Manipulating GA biosynthesis pathway in transgenic plants by genetic engineering offers an alternative way of producing sterile lines. Proper knowledge of these processes is very important in the field of plant breeding especially for hybrid seed production.

Gibberellin is a phytohormone that contains a tetracyclic diterpenoid structure that regulates various processes in plants like seed germination, stem elongation, leaf expansion, pollen and flower development. Further, they mediate environmental stimuli, which modify the flux through the 
GA biosynthetic pathway. GA is synthesized via the terpenoid pathway, involving 12 step conversions (Yang et al. 2009). In the early GA biosynthesis pathway, transgeranylgeranyl diphospate (GGDP) is converted to the tetracyclic hydrocarbon ent-kaurene via ent-copalyl diphosphate (CDP) by catalyzing ent-copalyl diphosphate synthase (CPS) and ent-kaurene synthase (KS) in plastid. The entkaurene is converted to $\mathrm{GA}_{12}$ via ent-kaurene acid by sequential oxidations of ent-kaurene oxidase (KO) and ent-kaurenoic acid oxidase (KAO). After that, $\mathrm{GA}_{12}$ and $\mathrm{GA}_{53}$ are converted to other GAs through two parallel pathways: early-13-hydroxylation and non-13-hydroxylation pathways. In the early-13-hydroxylation pathway, $\mathrm{GA}_{12}$ is converted to $\mathrm{GA}_{53}$ by GA13 oxidase. $\mathrm{GA}_{12}$ and $\mathrm{GA}_{53}$, via two parallel pathways, are converted to $\mathrm{GA}_{15} / \mathrm{GA}_{24} / \mathrm{GA}_{9}$ and $\mathrm{GA}_{44} / \mathrm{GA}_{19} / \mathrm{GA}_{20}$, respectively. And then, GA3-oxidase modifies $\mathrm{GA}_{9}$ and $\mathrm{GA}_{20}$ to bioactive $\mathrm{GA}, \mathrm{GA}_{4}$ and $\mathrm{GA}_{1}$, respectively. Besides, $\mathrm{GA}_{20}$ is converted to $\mathrm{GA}_{5}$ which is modified into $\mathrm{GA}_{6}$ and $\mathrm{GA}_{3}$ by GA3-oxidase. Finally, $\mathrm{GA}_{4}$ and $\mathrm{GA}_{1}$ are inactivated by $\mathrm{GA} 2$-oxidase to $\mathrm{GA}_{34}$ and $\mathrm{GA}_{8}$ (Fig. 1). Seven enzymes have been identified to be responsible for GA biosynthesis and function in multiple locations within the cell, including the chloroplast, the membrane and cytoplasm. These enzymes can be divided into two groups: the enzymes catalyzing early step such as CPS, KS, KO, KAO and the enzymes for late steps which include GA20ox, GA3ox, GA2ox (Sakamoto et al. 2004). In rice genome, 29 candidate genes for seven GA metabolic enzymes were identified including the four CPS- like, nice KS-like and five KO-like (Sakamoto et al. 2004).

Early studies suggested that GA has an important role in flower development. Jacobsen et al. (1994) isolated a mutant in tomato (Lycopersicon esculentum Mill.), gibl, which is GA-deficient mutant exhibiting various phenotype including abnormal flower development. In Arabidopsis, the expression of gal mutant induced nonviable pollen grain, resulting in poorly developed anthers (Goto and Pharis 1999). Previous results have also insisted that GAs were important for pollen germination and elongation (Singh et al. 2002). Although the action of GA was explained based on the constructive model of GA perception by Tanaka et al. (2007), however, the molecular mechanism downstream of DELLA degradation remains unclear (Aya et al. 2009). GA-deficient mutants have been isolated and also demonstrated the relation to dwarfism trait in rice that the most important valuable trait in rice breeding (Itoh et al. 2001; Sasaki et al. 2002; Qiao et al. 2007). GA signaling induces large scale downstream transcriptional changes that otherwise repressed by the DELLA sub-family of the GRAS domain protein in the absence of bioactive GA (Plackett et al. 2011). GAMYB, which has been known to function downstream of DELLA protein degradation, was

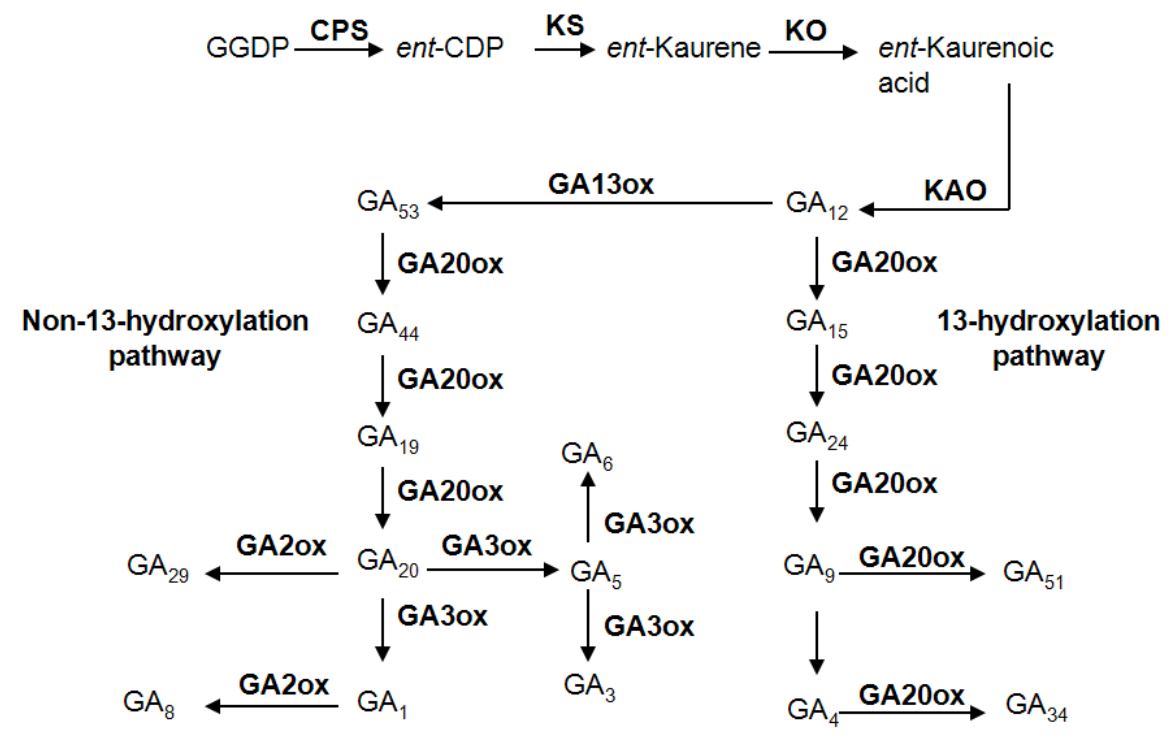

Fig. 1. Gibberellic acid biosynthetic pathway in plants. 
isolated as a positive GA signaling component. GAMYB express in cereal aleurone cell, inflorescence shoot apical region, stamen primordia, and tapetum cells of the anther (Kaneko et al. 2004) and plays important role in flower development, especially in anther development (Aya et al. 2009). The molecular function of GAMYB has been investigated by isolating loss-of-function mutants from a panel of rice mutants by the insertion of a retrotransposon, Tos 17 (Kaneko et al. 2004). Results showed that the Tos 17 had knocked out OsGAMYB function. The research group also identified two target genes of GAMYB encode lipid metabolic enzymes, cytochrome P450 hydroxylase (CYP703A3) and $\beta$-ketoacyl reductase (KAR). CYP703A3 is the same defects seen in the gamyb mutants which exhibit common defects in programmed cell death of tapetal cells, Ubisch body and exine formation (Koichiro Aya et al. 2009). The results indicated that all GA-related mutants cause abnormal event during anther development. GA-deficiency or insensitivity also causes defective Ubisch body formation in tapetal cells, seriously affecting the formation of exine.

Jasmonic acid (JA) has been known as the plant growth regulators acting as signals for plant development and induces changes in gene expression (Wasternack and Parthier 1997). JA was also identified as a factor affecting anther dehiscence. JA plays an essential role in pollen maturation and anther dehiscence in Arabidopsis, where linolenic acid (LA), the substrate for JA synthesis, is required for male sterility (Sanders et al. 2000: Ishiguro et al. 2001). JA biosynthetic pathway has been well characterized in plants (Liechti and Farmer 2002). JA biosynthesis begins with LA which is then converted to JA via several steps (Fig. 2). Allene oxide synthase (AOS) is a key enzyme in the JA biosynthesis pathway which catalyzes the dehydration of 13-hydroperoxylinoleic acid to 12,13-epoxylinolenic acid, which is then converted by allene oxide cyclase to cyclopentenone ring containing 12-oxo-phytodienoic acid, the direct precursor of JA (Creelman and Mullet 1997).

In Arabidopsis, the defective in anther dehiscencel ( $d a d 1$ ) gene encodes a phospholipase A1 that catalyzes the initial step of JA biosynthesis (Ishiguro et al. 2001). The action of $d a d l$ is restricted to the anthers filament immediately before flower opening. The male sterile mutant delayeddehiscence2-2 is defective in the processes of anther dehiscence and filament elongation (Von Malek et al. 2002), which result from a mutation in $A O S$ gene. Four $A O S$ genes were cloned (OSAOS1, OsAOS2, OSAOS3, OsAOS4) but only two (OsAOS1 and OsAOS2) were characterized until now (Agrawal et al. 2002; Ha et al. 2002; Haga and lino 2004). Further, the role of JA was also reported in several crops such as in soybean (Creelman and Mullet 1995) and Pinus pinaster (Pedranzani et al. 2007), and tomato (Pedranzani et al. 2003).

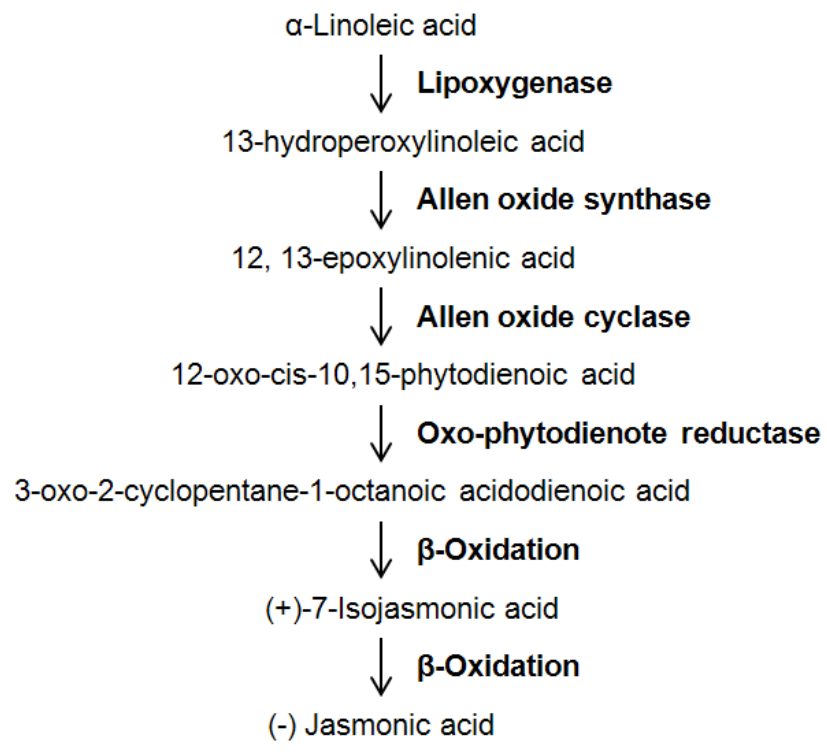

Fig. 2. Jasmonic acid biosynthetic pathway in plants. 
In rice, an increasing jasmonate levels in leaves and roots caused by JA biosynthesis genes have been demonstrated (Kiribuchi et al. 2005; Tani et al. 2008). Recently, the expression of jasmonic acid carboxyl methyltransferase (AtJMT) under the control of Ubil promoter increased the levels of methyl jasmonate (MeJA) by 6-fold in young panicles (Kim et al. 2009). Numbers of spikelet organs: the lemma or palea, lodicule, anther and pistil were altered in transgenic plants. Through RNAi, Bae et al. (2010) inserted OsAOS1 and OsAOS2 gene into rice under the control of the $O s g 6 b$ promoter, resulting in a complete or severe sterility phenotype compared with non-transgenic plants.

\section{Male sterility in rice}

The era of green revolution brought about dramatic yield breakthroughs especially on rice. However, the yield of semi-dwarf varieties had reached a plateau and there is a need to produce new varieties that produce more yields to meet the demands of the increasing population. To compensate with the need, Chinese scientists developed the hybrid breeding system that utilizes the concept of heterosis. Hybrid seeds perform 15 to $30 \%$ yield increase compared with inbred varieties grown under similar conditions (Fujimura et al. 1996), and hybrids have also responded better under adverse conditions of environment (Virmani et al. 2003). The production of $\mathrm{F}_{1}$ progeny superior from both parents in terms of yield, panicle number, and panicle size is very useful for agriculture. Heterosis is only applicable on the first generation, so farmers have to use new seeds every planting season to sustain the high yield of hybrid rice. Rice is highly self-pollinating so the removal of pollen is an important step in the development of male sterile lines. So far scientists had attempted to produce male sterile lines to make new hybrid rice varieties with higher yield as well as higher quality.

Male sterility can be genetic or non-genetic. Male sterility can be observed in lines in which pollen are unviable so that plant cannot reproduce by selfing. This line is used as the female parent. Male sterility was reported first time by Achimowitsh in 1931 on sugar beet. After that there were many detailed studies utilizing the male sterility for hybrid seed production. There are two kinds of male sterility systems, the cytoplasmic genic male sterility (CGMS) and environment genic male sterility (EGMS). Another system utilizes chemicals to induce male sterility (Virmani et al. 2003).

In nature, the most common form of sterility is the CGMS which is inherited maternally to produce nonfunctional pollen (Budar and Pellletier 2000). Cytoplasmic male sterility was first described by Edwardson (1956). To date, 20 independent CGMS have been reported in rice (Balaji Suresh et al. 2012), however, three of them, wild abortive (WA), Boro Tai (BT) and Honglian (HL) are mostly applied for commercial hybrid seed production ( $\mathrm{Li}$ and Yuan 2000; Fujii and Toriyama 2009). The causes of cytoplasmic male sterility are related to abnormal behavior of the tapetal cell (Che et al. 1972); the structural changes in the stamen filament; callose dissolution (Izhar and Frankel 1973); virus (Frankel 1956, 1962; Edwardson and Corbetts 1961; Edwardson 1956); differences of amino acid components in anther (Fukasawa 1954) and enzymatic activities (Fukasawa 1954; Larser and Lerstein 1972). Cytoplasmic male sterility is under the control of both mitochondrial and nuclear genome, resulting from the reaction between factor $\mathrm{S}$ in the cytoplasm and nuclear genes (Newton 1988; Levings and Brown 1989). Male fertility can be restored through block or compensate for cytoplasmic dysfunctions (Cui et al. 1996). The hybrid rice varieties that were produced based on CGMS system are usually called three line-hybrid rice which involve three lines including CGMS line (A), maintainer line (B), and restorer line $(\mathrm{R})$. The seeds of CGMS line are crossed with $B$ lines. The fertility of the $F_{1}$ seed is restored by crossing it with $R$ line.

Basically, there are two different kinds of cytoplasm, the normal $(\mathrm{N})$ and sterile $(\mathrm{S})$ cytoplasm. Located in the nuclear genome is restorer of fertility $(R f)$ genes which is a requirement to bring back the fertility in $\mathrm{S}$ cytoplasm. It is only expressed in the presence of the sterile cytoplasm. Several previous reports demonstrated the relationship of $R f$ gene and sterile cytoplasm (Tang et al. 1996). CGMS can be restored by $R f$ genes associated with nuclear genes mostly encoding pentatricopeptide repeat (PPR) proteins (Hanson and Bentolila 2004). Mitochondrial and nuclear interaction is crucial in the three-line system. The first isolated restorer of fertility gene was on maize $R f 2$ (Cui et al. 1996) which codes for aldehyde dehydrogenase. However 
on rice, $R f-1$ gene was found to code for a 791-aa protein containing mitochondrial targeting sequence in the $\mathrm{N}$-terminal region and 35-aa PPR motif. This result was similar with petunia $R f$ (Bentolila et al. 2002) and radish $R f k l$ (Niemelä et al. 2012) which also encodes for 14 repeats and 16 repeats of PPR, respectively. Similarly, these four genes were found to contain putative mitochondrial targeting sequence. It was also known that the PPR protein alters the expression of CGMS associated genes (Komori et al. $2004)$. In the presence of the nuclear gene, $R f$, suppression and restoration of male sterile phenotype is possible (Bentolila et al. 2002). CGMS eliminates the possibility of self-pollination and delimits the laborious method of emasculation. The role of PPR is not yet known but evidences support its function in the gene expression of organelles by binding to specific transcripts. Through positional cloning, $R f 1$ gene in rice was found to contain duplicate open reading frames ( $R f-1 A$ and $R f-1 B$ ) with PPR motif which lies on the 22.4-kb region. $R f-1 A$ was the suspected $R f$ gene since it has a mitochondrial targeting signal and possess transcript from an atp6/orf79 region of the mitochondrial genome (Akagi et al. 2004). Many research groups used molecular markers for studying gene functions. Shinjyo and Sato (1994) have isolated $R f 2$ from CGMS line of japonica (Nipponbare) and mapped the gene on chromosome 2. $R f 3$ and $R f 4$ have also been identified on chromosome 1 and 10, respectively from WA-CGMS line (Zhang et al. 1997; Yao et al. 1997; Ahmadikhah and Karlov 2006). By using rice microsatellite or simple sequence repeat (SSR), both $R f 3$ and $R f 4$ have been identified in different donors (Sattari et al. 2008; Nematzadeh and Kiani 2010). Balaji Suresh et al. (2012) performed mapping of $R f 3$ and $R f 4$ loci in the mapping population consisted of $1,500 \quad F_{2}$ progenies derived from hybrids viz. KRH2 (IR58025A/KMR3R) and DRRH2 (IR68897A/DR714-1-2R). The findings suggested that $R f 3$ and $R f 4$ loci are key in developing a marker system for identification of fertility restorers for WA-CGMS. In previous studies, Huang et al. (2000) fine-mapped the Rf5 (t) on chromosome 10 for HL-CGMS while another locus $R f 6(\mathrm{t})$ was also identified on the same chromosome and cytoplasm (Liu et al. 2004). The $S 24$ gene that was reported by Kubo et al. (2011) causes male sterility in combination with a sterility locus located on chromosome 2, EFS (Epistatic Factor for S24). In a related study, Reflinur et al. (2012) used a total of 107 and 144 STS markers covering 12 rice chromosomes in two reciprocal $\mathrm{F}_{2}$ and eight $\mathrm{BC}_{1} \mathrm{~F}_{1}$ populations respectively from a cross between Ilpumbyeo (japonica) and Dasanbyeo (indica), to identify QTLs associated with female and male sterility. Four QTLs, $q S F 5.1$ and $q S F 5.2$ on chromosome 5, qSF6.2 on chromosome 6, qSF12.2 on chromosome 12 were identified. $q S F 5.1, q S F 6.1$ and $q S F 6.2$ were found responsive to both female and male sterility, whereas $q S F 3.1, q S F 7, q S F 9.1$ and $q S F 12.2$ affected the spikelet.

The CGMS system has a limitation on restorer germplasm, a complex procedure for parental seed production and time consuming breeding of CGMS (Virmani 1994). Martin and Crawford (1951) were the first to observe the occurrence of temperature and light-sensitive reversible male sterile mutants in tomato and pepper. Similarly, Ahokas and Hockett (1977) reported this on barley. In rice, new technological approaches to replace the CGMS system are explored (Shin and Deng 1986; Lu and Wang 1988; Maruyama et al. 1990b; Virmani 1992; Ali et al. 1995) and have established as practical method in which germplasms are available as parents and maintainer line is not needed (Yuan 1994). This new system is based on environmentsensitive genetic male sterile (EGMS) line, such as those that are modulated by photoperiod or temperature (Virmani 1994). In EGMS, only two lines are involved to produce a hybrid seed. One line is male sterile in which the fertility is affected by changes in the environment (temperature, photoperiod or both) and the other one is any inbred variety. The male sterile lines which expression of sterility is controlled by the environment are photoperiod-sensitive genic male sterile (PGMS) and thermo-sensitive genic male sterility (TGMS) lines. This system does not require maintainer lines and any line can be used as pollen donor. However, any sudden changes in the environmental condition can affect the sterility of the lines and it is also limited by proper timing and space.

PGMS lines are sensitive to changes in the length of days in the expression of fertility or sterility. Nongken58S was the first discovered japonica rice which exhibited photosensitive male sterility in Hubei Province, China. The seeds of Nongken58S are sterile under long-day period 
(14h) and fertile under short day period $(<13.75 \mathrm{~h}, 10-40 \%$ spikelet fertility) (Shi and Deng 1986; Lu and Wang 1988). The previous discoveries showed that most PGMS lines of japonica subspecies were male sterile under long-day period $(>13 \mathrm{~h})$ and revert to fertility under short-day conditions ( $<13 \mathrm{~h}$ ), such as MSR 54A (B) (Lu and Wang 1988), EGMS (Rutger and Chalter 1989). Another japonica variety, Zhenong $1 \mathrm{~S}$, is also completely male sterile under long-day conditions and revert to fertility under short-day conditions, but it was also influenced by temperature (Dong et al. 1993). In the previous surveys, the male sterility of indica subspecies under long-day conditions was found similar to japonica. However, fertility was recovered under conditions less than $12 \mathrm{~h}$, such as that of CIS 28-10S (Huang and Zhang 1991) and 26 ZhaiZao (Shen et al. 1994).

In TGMS, fertility and sterility is affected by the changes in temperature. Ali and Sididiq (1999) classified TGMS into two types: (1) high temperature sterility and low temperature fertility; (2) high temperature fertility and low temperature sterility. Annong 1S was the first identified TGMS that remain sterile under relatively higher temperature $\left(33^{\circ} \mathrm{C}\right.$-day and $28^{\circ} \mathrm{C}$-night) and turn fertile under low temperature $\left(27^{\circ} \mathrm{C}\right.$-day and $22^{\circ} \mathrm{C}$-night) (Yang and Wang 1990; Sun et al. 1989). Most of the indica rice varieties are sterile under high temperature (day temperature $>30^{\circ} \mathrm{C} /$ night $>24^{\circ} \mathrm{C}$ ) and fertile under low temperature (day $<24^{\circ} \mathrm{C} />16^{\circ} \mathrm{C}$ night), for example, JP2, SM 3, SM5, SA 2, F61, ID 24, JP 8-8-1 S (Ali et al. 1995). By contrast, some indica subspecies such as JP 38, W6154s IV A succumb to sterility at low temperature $\left(<24^{\circ} \mathrm{C}\right)$ and revert to fertility at high temperature $\left(>30^{\circ} \mathrm{C}\right)$ (Zhang et al. 1991).

Generally, percentage of male sterility in rice is not only influenced by day length conditions but also by temperature. Fertility or sterility changes in photoperiod-temperature genic sensitive male sterility (PTGMS) lines are closely related to the combination of photoperiod and temperature. Dong et al. (1993) indicated that the turn ability of fertility of Zhenong $1 \mathrm{~S}$ variety is not only controlled by short-day conditions but also by low temperature $\left(25.7^{\circ} \mathrm{C}\right)$. Many reports showed that sterility/fertility could be prone to the influence of temperature (He et al. 1987; Zhang et al. 1987). Although, Cheng et al. (1990) indicated that
Nongken $58 \mathrm{~S}$ variety was sterile/fertile under day length conditions. However other studies suggested that this line was influenced more by temperature than photoperiod (Wan and Deng 1990; Sun et al. 1991). Both PGMS and PTGMS systems were limited by temperature and light time.

To clearly understand the relationship between male sterility and environmental factors, several scientists have isolated relative candidate genes. Fertility is controlled by one or two major Mendelian loci (Shi 1985). Genes governing photoperiod sensitive male sterility in rice was characterized by Mei et al. (1990) and Zhang et al. (1994). In these studies pms 1, pms 2 and $p m s 3$ genes were localized on chromosome 7, 3 and 12. The effect of pms 1 on pollen fertility was much larger than that of pms2 (Zhang et al. 1994). To date, ten genes related to TGMS have been identified. These are tms 1 of $5460 \mathrm{~S}$ line from China (Wang et al. 1995), tms2 of Norin PL12 from Japan (Yamagushi et al. 1997), tms3(t) of IR32364TGMS line from IRRI (Subudhi et al. 1997), tms4-1 of TGMS-VN1 line from Vietnam (Dong et al. 2000), tms4-2 (Reddy et al. 2000), tms 5 and tms6-1 of AnnongS-1 line from China (Wang et al. 2003), tms6-2 of Sokcho-MS line from Korea (Lee at al. 2005), rtms 1 of J207S line (Jia et al. 2001), and $m s$ - $h$ of Hwacheong ms-h line (Koh et al. 1999). Each was localized on chromosome 8, 7, 6, 2, 2, 10 and 9, respectively.

In addition, several enzymes that play important role in male sterility were studied. Adenine phosphoribosyl transferase (APRT) is the major enzyme for converting adenine into adenosine-3'-phosphate (AMP) associated with the purine salvage pathway. APRT gene mutation causes the male sterility in Arapidopsis (Gaillard et al. 1998). In rice, APRT gene and TGMS phenotype were investigated ( $\mathrm{Li}$ et al. 2003). The findings indicated that the $A P R T$ gene contains six introns. The transcription of $A P R T$ gene is down-regulated in TGMS rice line Annong S-1 by high temperature stress $\left(28^{\circ} \mathrm{C}\right)$ that perhaps results in the pollen abnormal development (Li et al. 2003). Liang et al. (2004) treated the leaf, root and young panicle of TGMS line AnnongS-1 by low and high temperature. Results showed that the low temperature treatment in the root did not significantly induce Annong S-1 to be fertile. By contrast, young panicle obviously induced Annong S-1 to be fertile at low temperature. The expression of $A P R T$ gene in young panicle was greatly 
down-regulated by high temperature causing the male sterility of Annong S-1, while its expression in the root and leaf have no major changes. Abe et al. (2002) identified two homologous UDP-glucose pyrophosphorylase (UGPase) genes in rice genome, the UGPasel located on chromosome 9 and UGPase 2 on chromosome 2. Both are ubiquitously expressed throughout rice development, however, only UGPasel transcripts are present at higher level in florets before flowering (Abe et al. 2002). UDPG is a key substrate of the enzyme for carbohydrate metabolism in both source and sink tissue (Gibeaut 2000). Woo et al. (2008) generated male sterile rice transgenic plants by inserting UGPaseRNAi construction into Hwacheong cultivar. In a similar approach OsGEN-L (OsGEN-like) which belongs to RAD2/XPG nuclease family was isolated from japonica rice Toride 1 (Moritoh et al. 2005). Also, the gene function was elucidated. Most of transgenic plant with OsGEN-L-RNAi construction displayed low fertility or were male sterile. It was suggested that $O S G E N-L$ plays important role in DNA metabolism required for early microspore development in rice. In a study by Ku et al. (2003) TGMS is associated with premature programmed cell death (PCD) of the tapetum. The sterility is caused by the PCD in the early stages of the pollen development which causes failure to develop new pollen.

Although CGMS and EGMS facilitated the success in rice hybrid production both systems have disadvantages. CGMS is rather complicated because of the technical complexity of hybrid production itself. This makes seed production using two parents simpler than CGMS system. EGMS does not need a maintainer line for seed multiplication but induction of male sterile/fertile line is controlled by environmental factors that are impossible to control. Aside from using the three-line or two-line method, one useful method of inducing sterility is by the application of chemicals. Various potential chemical hybridizing agents (CHAs) was used for hybrid rice seed production such as ethylene (Perez et al. 1973), arsenates (Chen et al. 1986), oxanilates and plant growth hormones (Ali et al. 1999). However, CHAs may be unsafe for human health. This prompted many scientists to explore the relationship of male sterility/fertility and metabolic biosynthesis pathway.

Many of the male-sterile mutants exhibited abnormal plant hormone contents at flower development stage. And a number of studies also documented the hormonal changes and critical hormone at flower development (Kaneko et al. 2003; Sakamoto et al. 2004; Hirano et al. 2008). Huang et al. (2003) reported that deficiency of endogenous gibberellin or cytokinin can induce abnormal flower development and exogenous hormone treatment can restore normal flower development.

\section{Engineering of male sterile mutants}

Many different approaches have been reported for the production of male sterile plants, such as male sterile induction by interfering the development and metabolic synthesis of the tapetum (Van de Meer et al. 1992; Hernould et al. 1998) or pollen (Worrall et al. 1992) in transgenic plants. Male sterility was also induced by using sense or antisense suppression to inhibit essential genes (Xu et al. 1995; Luo et al. 2000) or by expressing aberrant mitochondrial gene products (Hernould et al. 1993; He et al. 1996; Gomez et al. 2002). One way to achieve male sterility is the use of gene that encodes a protein which is able to disrupt cell function (Mariani et al. 1990, 1992; Burgess et al. 2002). Barnase/Barstar is a useful system for male sterility using tapetal specific promoter TA29 that drives expression of the barnase gene, inducing male sterile plants (Mariani et al. 1990, 1992). In transgenic Nicotiana tabacum plants, the $\arg E$ gene products that were controlled by tapetal specific promoter Ta29 lead to empty anthers, resulting in male sterile plants (Kriete et al. 1996). Similarly, Roque et al. (2007) fused the PSEND1 promoter to the barnase gene which permits identification of male sterile line before flowering. The PSEND1 is an anther-specific promoter that drives gene expression in a tightly specific pattern restricted to developing anther. This promoter was widely applied in species such as Arabidopsis, oilseed rape, rice, and wheat (Gomez et al. 2004; Piston et al. 2008). The other way to introduce male sterility is the use of diphtheria toxin A-chain that is expressed in a tissue-specific manner (Koltunow et al. 1990).

Other approach to induce male sterility is to change the levels of metabolites needed for the anther and pollen development. The deficit of carbohydrates in plant can lead to male sterility. Many previous studies have indicated the crucial function of extracellular invertase in proving 
carbohydrates to the male gametophyte in different species. For example, the early stages of pollen development of tobacco are blocked by the expression of extracellular invertase Nin 88 gene under the control of tissue-specific promoter Nin88, resulting in male sterility in tobacco (Goetz et al. 2001). A novel gene MSP1 (Multiple sporocyte) that controls early sporogenic development was elucidated by Nonomura et al. (2003). Results implicated that the MSPI gene encodes a leu-rich repeat receptor-like protein kinase. The formation of anther wall layer was disordered and the tapetum layer was lost completely because of the expression of the mspl gene mutation. The development of pollen mother cells was obstructed at various stages of meiotic prophase I, resulting to complete male sterility. These results suggest that the $M S P 1$ gene plays crucial roles in restricting the number of cells entering into male and female sporogenesis and in initiating anther wall formation in rice. In a similar study by Wang et al. (2006), the mutant msp 1-4 gene was isolated from japonica cultivar 9522. Phenotypic analysis indicated that the mspl-4 was similar to mspl mutant gene. The mspl-4 gene product reduced expression level of rice UDT1 and GAMYB which play role to regulate rice early anther development. In the paper published by Zhao et al. (2008), they mentioned that rice contains two tapetum determinant 1 (TPD1) like gene, the OsTDL1A and OSTDL1B. Although both are co-expressed with $M S P 1$ gene in anthers during meiosis but only OSTDL1A and MSP1 are co-expressed in the ovule. They concluded that OSTDL1A binds MSP1 in order to limit sporocyte numbers in rice. The male sterile microspore and tapetum regulator 1 ( $\mathrm{mtr} 1$ ) mutant was isolated from the japonica subspecies by Tan et al. (2012). Highlights of phenotypic analyses indicated that floral organ has smaller and pale yellow anthers which fail to produce viable pollen grains. The MTR1 locus is located on chromosome 12, containing two putative fasciclin domains, FAS1-1 (amino acids 254-356) and FAS1-2 (amino acids 435-535), which are indispensible for role of MTR1 in anther development and pollen maturation. Fasciclin domain is also known to be an extracellular module putatively mediates cell adhesion (Faik et al. 2006; MacMillan et al. 2010). Ruiz and Daniell (2005) demonstrated the role of phaA gene which encodes $\beta$-ketothiolase from bacterium Acinetobacter into the chloroplast genome of tobacco under the control of

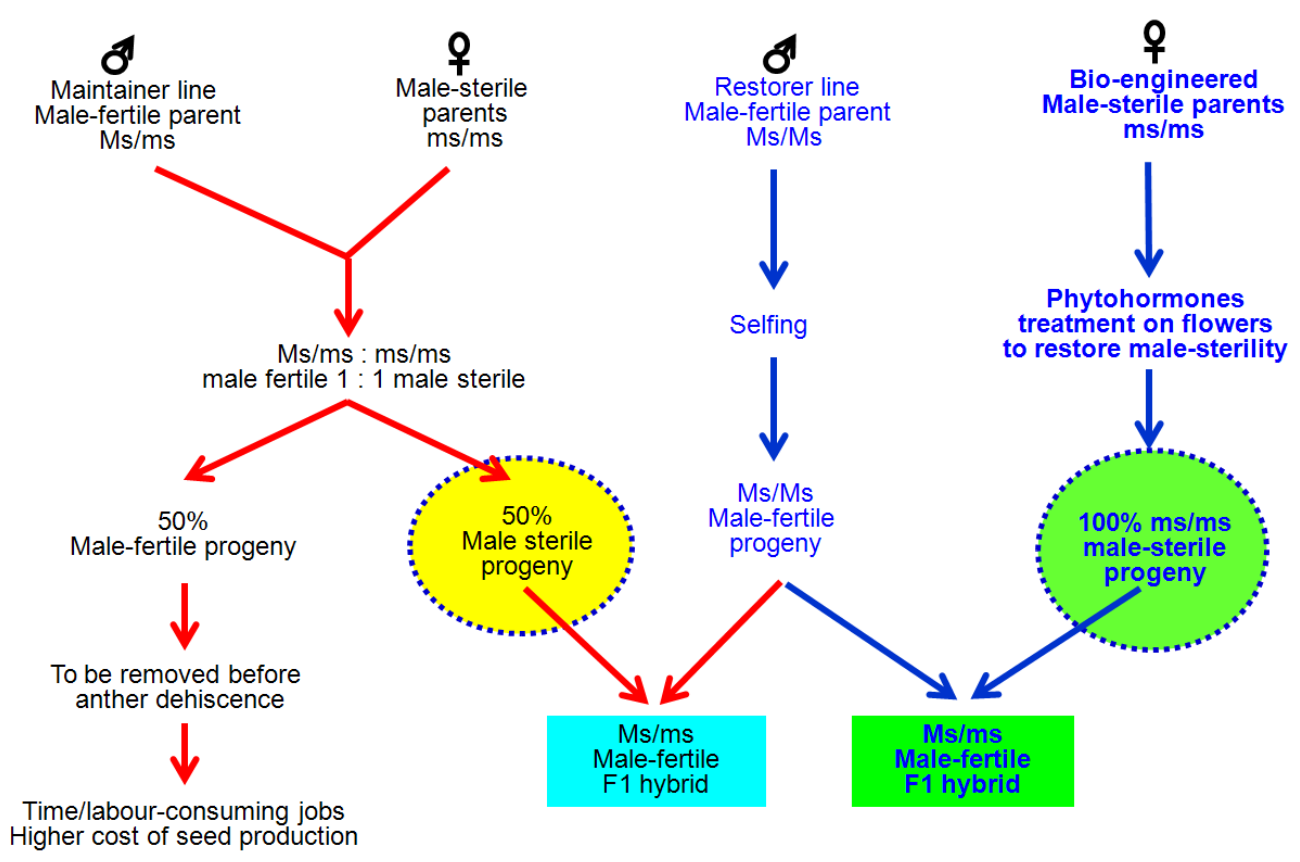

Fig. 3. Bioengineering system for the generation of male sterile plants. Bio-engineered male-sterile plants can be generated by RNA interference-approaches to inhibit the biosynthesis of endogenous hormones in developing pollen under the control of tissue-specific promoters. 
chloroplast promoter $p s b A$. The expression of $\beta$-ketothiolase accelerates anther development and causes the pollen grains to collapse, leading to male sterility. This is a promising approach to induce male sterility in plants (Khan 2005).

The combination of recombinant DNA technology and genetic transformation method have provided new possibilities for inducing male sterility which will be extremely valuable for hybrid production. Targeted breakdown of developing pollen by tagging a cytoxin gene under the control of a tapetum/pollen-specific promoter and restoring fertility by the suppression of mRNA expressed in the tapetum using an antisense approach has been made possible (Mariani et al. 1990, 1992). In order to generate EGMS plant for the establishment of two-parent system, fertility can be easily regulated by simple treatment in the field such as through hormonal application into male reproductive tissue at appropriate stage. To fulfill this requirement, one feasible way is the use of deficiencies in endogenous hormones level in male reproductive tissue that result in the delay or elimination of anthesis causing male sterility which can be restored into fertility (Fig. 3).

For the induction of male-sterility through recombinant DNA technology, another important factor is the use of appropriate promoter which act in male gametophytespecific manner, not expressed in other sporophytic anther tissues. Also, a predictable disadvantage associated with the use of male gametophytic-specific promoter is the low frequency or lack of homozygous progeny due to the reduced genetic transmission through male gametes as shown in the mutant of rice immature pollen1 (Han et al. 2006). Bae et $a l$. (2010) fused Osc4 and Osg6b promoter with allene oxide synthase (OSAOS) that catalyzes the biosynthesis of jasmonic acid in rice. They concluded that $O s g 6 b$ is the most effective promoter for inducing male sterility in rice by RNAi.

\section{CONCLUSION}

Male sterility in rice is essential factor in hybrid breeding which has been considered as a useful tool for the improvement of productivity in rice. The combination of recombinant DNA technology and genetic transformation method provides new possibilities for the induction of male sterility which will be extremely valuable for hybrid seed production in crop. One way to achieve this is to inhibit endogenous hormone biosynthesis in developing pollen under the control of a tissue-specific promoter and restore fertility by the hormonal application on male reproductive tissue at appropriate stage (Fig. 3). Because the deficiencies in endogenous hormone level in pollen result in the delay or elimination of anthesis causing genic male sterility. Also complete male-sterility can be achieved in transgenic plants that are homozygous for the transgene, which can be maintained by exogenous hormonal supply. In addition, the restoration of fertility can lead to the production of $100 \%$ male-sterile progeny which can be used as female parents in $F_{1}$ seed production (Fig. 3). In this aspect, a critical factor is the use of appropriate promoter which is acting exclusively in pollen-specific manner, since the resulting $F_{1}$ plants may be affected morphologically or physiologically if heterozygous transgenes were expressed in other sporophytic tissues. The combination of these genes and tissue-specific promoters should allow us to design more efficient way for biotechnological application in rice breeding program.

\section{ACKNOWLEDGMENT}

This work was supported by a grant from the NextGeneration BioGreen21 Program, Rural Development Administration, Republic of Korea (Plant Molecular Breeding Center No. PJ008137).

\section{REFERENCES}

Abe T, Niiyama H, Sasahara T. 2002. Cloning of cDNA for UDP-glucose pyrophosphorylase and the expression of mRNA in rice endosperm. Theor. Appl. Genet. 105: 216-221.

Agrawal GK, Abe K, Yamazaki M, Miyao A, Hirochika H. 2005. Conservation of the E-function for floral organ identity in rice revealed by the analysis of tissue culture-induced loss-of-function mutants of the OsMADSI gene. Plant Mol. Bio. 159: 125-135.

Agrawal GK, Rakwal R, Jwa NS, Han KS, Agrawal VP. 
2002. Molecular cloning and mRNA expression analysis of the first rice jamonate biosynthetic pathway gene allene oxidase synthase. Plant Physiol. Biochem. 40: 771-782.

Ahmadikhah A, Karlov GI. 2006. Molecular mapping of the fertility-restoration gene $R f 4$ for WA-cytoplasmic male sterility in rice. Plant Breeding125: 63-367.

Ahokas H, Hockett EA. 1977. Male sterile mutants of Barley IV. Different fertility levels of $m s g 9 c i$ (cv. Ventage) an ecoclinal response. Barley Genet. Newslett. 7: 10-11.

Akagi H, Nakamura A, Yokozeki-Misono Y, Inagaki A, Takahashi H, Mori K, Fujimura T. 2004. Positional cloning of the rice $R f-1$ gene, a restorer of BT-type cytoplasmic male sterility that encodes a mitochondriatargeting PPR protein. Theor. Appl. Genet. 108: 1449-1457.

Ali AJ, Devakumar C, Zaman FU, Siddiq EA. 1999. Identi fication of potent gametocides for selective induction of male sterility in rice. Indian J. Genet. 59: 429-436.

Ali AJ, Siddiq EA. 1999. Isolation and characterization of a reverse temperature sensitive genic male sterile mutant in rice. Indian J. Genet. Plant Breeding 59: 423-428.

Ali AJ, Siddiq EA, Zaman FU, Abraham MJ, Ahmed IM. 1995. Identification and characterization of temperature sensitive genic male sterile sources in rice (Orysa sativa L.). Indian J. Genet. 55: 243-259.

Aya K, Tanaka MU, Kondo M, Hamada K, Yano K, Nishimura M, Matsuoka M. 2009. Gibberellin modulates anther development in rice via the transcriptional regulation of GAMYB. Plant Cell 21: 1453-1472.

Bae HK, Kang HG, Kim GJ, Eu HJ, Oh SA, Song JT, Chung IK, Eun MY, Park SK. 2010. Transgenic rice plants carrying RNA interference constructs of $A O S$ (allene oxide synthase) genes show severe male sterility. Plant Breeding 129: 647-651.

Balaji Suresh P, Srikanth B, Hemanth Kishore V, Subhakara Rao I, Vemireddy LR, Dharika N, Sundaram RM, Ramesha MS, Sambasiva Rao KRS, Viraktamath BC, Neeraja CN. 2012. Fine mapping of $R f 3$ and $R f 4$ fertility restorer loci of WA-CMS of rice (Oryza sativa L.) and validation of the developed marker system for identification of restorer lines. Euphytica 187: 421-435.

Bentolila S, Alfonso A, Hanson M. 2002. A pentatricopeptide repeat-containing gene restores fertility to cytoplasmic male-sterile plants. Proc. Natl. Acad. Sci. USA 99: 10887-10892.

Borg M, Brownfield L, Twell D. 2009. Male gametophyte development: a molecular perspective. J. Experimental
Botany 60: 1465-1478

Budar F, Pellletier G. 2000. Male sterility in plants: occurrence, determinism, significance and use. Life Science 324: 543-550.

Burgess DG, Ralston EJ, Hanson WG, Heckert M, Ho M, Jenq T, Palys JM, Tang K, Gutterson N. 2002. A novel, two-component system for cell lethality and its use in engineering nuclear male-sterility in plants. Plant J. 31: 113-125.

Causier B, Schwarz-Sommer Z, Davies B. 2010. Floral organ identity: 20 years of ABCs, Seminars Cell \& Developmental Biology 21: 73-79.

Chase CD. 2006. Genetically engineered cytoplasmic male sterility. Trends Plant Sci. 11: 8-9.

Che YE, Li YS, Shinjino C, Li HW. 1972. Hybrid rice breeding III. Cyto.histological investigation of pollen degeneration in anther of cytoplasmic male sterile plants. Jap. J. Genet. 47: 179-183.

Creelman RA, Mullet JE. 1995. Jasmonic acid distribution and action in plants: regulation during development and response to biotic and abiotic stress. Proc. Natl. Acad. Sci. USA 92: 4114-4119.

Creelman RA, Mullet JE. 1997. Biosynthesis and action of jasmonates in plants. Annu. Rev. Plant Physiol. Plant Mol. Biol. 48: 55-81.

Chen PL, Chen B, Chen JL, Ho LK. 1986. Arsenic content and castration effect in reaction to male gametocide no. 2 in rice plants. J. South China Agric. Univ. 7: 22-27.

Chen ZX, Wu JG, Ding WN, Chen HM, Wu P, Shi CH. 2006. Morphogenesis and molecular basis on naked seed rice, a novel homeotic mutation of OSMADSI regulating transcript level of AP3 homologue in rice. Planta 223: 882-890.

Cheng S, Sun ZX, Min SK, Xiong ZM, Yin CS. 1990. Studies in response to photoperiod and temperature of the photoperiod sensitive genic male sterile rice (PGMSR) I. Observation of fertility in PGMSRS under natural conditional at Hang Zhou (30'05'N). Chinese J. Rice Sci. 4: 157-162.

Cui R, Han J, Zhao S, Su K, Wu F, Du X, Xu Q, Chong K, Theißen G, Meng Z. 2010. Functional conservation and diversification of class $\mathrm{E}$ floral homeotic genes in rice (Oryza sativa). Plant J. 6: 767-781.

Cui X, Wise RP, Schnable PS. 1996. The rf2 nuclear restorer gene of male- sterile T-cytoplasm maize. Science 272: 334-336.

Deveshwar P, Bovill WD, Sharma R, Able JA, Kapoor S. 
2011. Analysis of anther transcriptomes to identify genes contributing to meiosis and male gametophyte development in rice. BMC Plant Biology 1: 78.

Dong NV, Subudhi PK, Luong PN, Quang VD, Quy TD, Zheng HG, Wang B, Nguyen HT. 2000. Molecular mapping of a rice gene conditioning thermosensitive genic male sterility using AFLP, RFLP, and SSR techniques. Theor. Appl. Genet. 100: 27-34.

Dong Y, Shi S, Zhang H. 1993. Fertility of Zhenong 1S a promising photoperiod sensitive genic male sterile (PGMS) japonica rice. Int. Rice Res. Newsl. 18: 13.

Edwardson JR. 1956. Cytoplasmic male sterility. Bot. Rev. 22: 696-738.

Edwardson JR, Corbett MK. 1961. A sexual transmission of cytoplasmic male sterility. Froc. Nat. Acad. Sci. 47: 390-396.

Faik A, Abouzouhair J, Sarhan F. 2006. Putative fasciclinlike arabinogalactan-proteins (FLA) in wheat (Triticum aestivum) and rice (Oryza sativa): Identification and bioinformatic analyses. Mol. Genet. Genomics 276: 478-494.

Frankel R. 1956. Graft-induced transmission to progeny of cytoplasmic male sterility in petunia. Science 124: 684 -685 .

Frankel R. 1962. Further evidence of graft induced tranission to progeny of cytoplasmic male sterility in petunia. Genetics 47: 641-646.

Fujii S, Toriyama K. 2009. Suppressed expression of retrograderegulated male sterility restores pollen fertility in cytoplasmic male sterile rice plants. Proc. Natl. Acad. Sci. USA 106: 9513-9518.

Fujita M, Horiuchi Y, Ueda Y, Mizuta Y, Kubo T, Yano K, Yamaki S, Tsuda K, Nagata T, Niihama M, Kato H, Kikuchi S, Hamada K, Mochizuki T, Ishimizu T, Iwai H, Tsutsumi N, Kurata N. 2010. Rice expression atlas in reproductive development. Plant Cell Physiol. 51: 2060-2081.

Fujimura T, Akagi H, Oka M, Nakamura A, Sawada R. 1996. Establishment of a rice protoplast culture and application of an asymmetric protoplast fusion technique to hybrid rice breeding. Plant Tissue Cult. Lett. 13: 243-247.

Fukasawa H. 1954. On the free amino acids in anthers of male-sterile wheat and maize. Jap. J. Genet. 29: 135-137.

Gaillard C, Moffatt BA, Blacker M, Laloue M. 1998. Male sterility associated with APRT deficiency in Arabidopsis results from a mutation in the gene APT1. Mol. Gen.
Genet. 257: 348-353.

Gao XC, Liang W, Yin C, Ji S, Wang H, Su X, Guo C, Kong H, Xue H, Zhang D. 2010. The SEPALLATA-Like gene OsMADS34 is required for rice inflorescence and spikelet development. Plant Physiology 153: 728-740.

Gibeaut DM. 2000. Nucleotide sugars and glycosyltransferases for synthesis of cell wall matrix polysaccharides. Plant Physiol. Biochem. 38: 69-80.

Gomez M, Beltran JP, Canas L. 2004. The pea END1 promoter drives anther-specific gene expression in different plant species. Planta 219: 967-981.

Goetz M, Godt DE, Guivarch A, Kahmann U, Chriqui D, Roitsch T. 2001. Induction of male sterility in plants by metabolic engineering of the carbohydrate supply. Proc. Natl. Acad. Sci. USA 98: 6522-6527.

Gómez-Casati DF, Busi MV, Gonzalez-Schain N, Mouras A, Zabaleta EJ, Araya A. 2002. A mitochondrial dysfunction induces the expression of nuclear-encoded complex I genes in engineered male sterile Arabidopsis thaliana. FEBS Lett. 532: 70-7.

Goto N, Pharis RP. 1999. Role of gibberellins in the development of floral organs of gibberellin-deficient mutant, ga1-1, of Arabidopsis thaliana. Can. J. Bot. 77: 944-954.

Ha SB, Lee BC, Lee DE, Kuk YI, Lee AY, Han OS, Back KW. 2002. Molecular characterization of the gene encoding rice alllene oxidase synthesis and its expression. Biosci. Biotechnol. Biochem. 66: 2719-2722.

Haga K, Iino M. 2004. Phytochrome-mediated transcriptional up-regulation of ALLENE OXIDE SYNTHASE in rice seedlings. Plant Cell Physiol. 45: 119-128.

Hanson MR, Bentolila S. 2004. Interactions of mitochondrial and nuclear genes that affect male gametophyte development. Plant Cell 16: S154-S169.

Han MJ, Jung KH, Yi G, Lee DY, An G. 2006. Rice immature pollen 1 (RIP1) is a regulator of late pollen development. Plant Cell Physiol. 47: 1457-1472.

Haughn G, Somerville C. 1988. Genetic control of plant morphogenesis. Dev. Genet. 9: 73-89.

He HH, Zhang ZG, Yuan SC. 1987. Response on development and fertility changes induced by light under different temperature condition in HPGMR. J. Wuhan Univ. 7: 87-93.

He S, Abad AR, Gelvin SB, Mackenzie S. 1996. A cytoplasmic male sterility-associated mitochondrial protein causes pollen disruption in transgenic tobacco. Proc. Natl. Acad. Sci. USA 93: 11763-11768. 
Hernould M, Suharsonno S, Litvak S, Araya A, Mouras A. 1993. Male-sterility induction in transgenic tobacco plants with an unedited atp 9 mitochondrial gene from wheat. Proc. Natl. Acad. Sci. USA 90: 1370-1374.

Hernould M, Suharsono S, Zabaleta E, Carde JP, Litvak S, Araya A, Mouras A. 1998. Impairment of tapetum and mitochondria in engineered male-sterile tobacco plants. Plant Mol. Biol. 36: 499-508.

Hirano K, Tanaka MU, Matsuoka M. 2008. GID1-mediated gibberellin signaling in plants. Trends Plant Sci. 13: 192-199.

Honys D, Twell D. 2004. Transcriptome analysis of haploid male gametophyte development in Arabidopsis. Genome Biol. 5: R85.

Hu L, Liang W, Yin C, Cui X, Zong J, Wang X, Hu J, Zhang D. 2011. Rice MADS3 regulates ROS homeostasis during late anther development. Plant Cell 23: 515-533.

Huang QC, Zhang XT. 1991. CIS 28-10s, a new indica photoperiod sensitive genic male sterile rice: Int. Rice Res. Newsl. 16: 8-9.

Huang QY, He QY, Jing RC, Zhu RS, Zhu YG. 2000. Mapping of the nuclear fertility restorer gene for HL cytoplasmic male sterility in rice using microsatellite markers. Chin. Sci. Bull. 45: 430-432.

Ikeda K, Sunohara H, Nagato Y. 2004. Developmental course of inflorescence and spikelet in rice. Breed. Sci. 54: 147-156.

Ishiguro S, Kawai-Oda A, Ueda K, Nishida I, Okada K. 2001. The DEFECTIVE IN ANTHER DEHISCENCE1 gene encodes a novel phospholipase A1 catalyzing the initial step of jasmonic acid biosynthesis, which synchronizes pollen maturation, anther dehiscence, and flower opening in Arabidopsis. Plant Cell 13: 21912209.

Itoh H, Tanaka MU, Sentoku N, Kitano H, Matsuoka M, Kobayashi M. 2001. Cloning and functional of the height-regulating gibberellin 3 $\beta$-hydroxylase genes that are differently expressed during the growth of rice. Proc. Natl. Acad. Sci. USA 98: 8909-8914.

Itoh JI, Nonomura KI, Ikeda K, Yamaki S, Inukai Y, Yamagishi H, Kitano H, Nagato Y. 2005. Rice plant development: from zygote to spikelet. Plant Cell Physiol. 46: 23-47.

Izhar S, Frankel R. 1973. Mechanism of male sterility in Petunia II. Free amino acids in male fertile and male sterile anthers during microsporogenesis. Theor. Appl. Genet. 41: 13-17.
Jacobsen SE, Shi L, Xin Z, Olszewski NE. 1994. Gibberellin induced changes in the translatable mRNA populations of stamens and shoots of gibberellin-deficient tomato. Planta 192: 372-378.

Jeon JS, Jang S, Lee S, Nama J, Kima C, Leeb SH, Chung YY, Kim SH, Lee YH, Cho YG, An G. 2000. leafy hull sterile1 is a homeotic mutation in a rice MADSbox gene affecting rice flower development. Plant Cell 12: 871-889.

Jia JH, Zhang DS, Li CY, Qu XP, Wang SW, Chamarerk V, Nguyen HT, Wang B. 2001. Molecular mapping of the reverse thermosensitive genic male-sterile gene (rtms1) in rice. Theor. Appl. Genet. 103: 607-612.

Jiang SY, Ramachandran S. 2010. Functional genomics of rice pollen and seed development by genome-wide transcript profiling and $D s$ insertion mutagenesis. Int. J. Biol. Sci. 7: 28-40.

Kaneko M, Inukai Y, Tanaka MU, Itoh $\mathrm{H}$, Izawa $\mathrm{T}$, Kobayashi Y, Hattori T, Miyao A, Hirochika H, Ashikari M, Matsuoka M. 2004. Loss-of-function mutations of the rice GAMYB gene impair alpha-amylase expression in aleurone and flower development. Plant Cell 16: 33-44.

Kaneko M, Itoh H, Inukai Y, Sakamoto T, Tanaka MU, Ashikari M, Matsuoka M. 2003. Where do gibberellin biosynthesis and gibberellin signaling occur in rice plants? Plant J. 35: 104-115.

Khan MS. 2005. Engineering cytoplasmic male sterility with $\beta$-ketothiolase. Nature 436: 783-785.

Kim EH, Kim YS, Park SH., Koo YJ, Choi YD, Chung YY, Lee IJ, Kim JK. 2009. Methyl jasmonate reduces grain yield by mediating stress signals to alter spikelet development in rice. Plant Physiology 149: 1751-1760.

Kiribuchi K, Jikumaru Y, Kaku H, Minami E, Hasegawa M, Kodama O, Seto H, Okada K, Nojiri H, Yamane H. 2005. Involvement of the basic helix-loop-helix transcription factor RERJ1 in wounding and drought stress responses in rice plants. Biosci. Biotechnol. Biochem. 69: 1042-1044.

Koh HJ, Son YH, Heu MH, Lee HS, McCouch SR. 1999. Molecular mapping of a new genic male-sterility gene causing chalky endosperm in rice (Oryza sativa L.). Euphytica 106: 57-62.

Koltunow AM, Truettner J, Cox KH, Wallroth M, Goldberg RB. 1990. Different temporal and spatial gene expression pattern occur during anther development. Plant Cell 2: 1201-1224. 
Komori T, Ohta S, Murai N, Takakura Y, Kuraya Y, Suzuki S, Hiei Y, Imaseki H, and Nitta N. 2004. Map-based cloning of a fertility restorer gene, $R f-1$, in rice (Oryza sativa L.). Plant J. 37: 315-325.

Kriete G, Niehaus K, Perlick AM, Pühler A, Broer I. 1996. Male sterility in transgenic tobacco plants induced by tapetum-specific deacetylation of the externally applied non-toxic compound N-acetyl-L-phosphinothricin. Plant J. 9: 809-818.

$\mathrm{Ku}$ S, Yoon H, Suh HS, Chung YY. 2003. Male-sterility of thermosensitive genic male-sterile rice is associated with premature programmed cell death of the tapetum. Planta 217: 559-565.

Kubo T, Yoshimura A, Kurata N. 2011. Hybrid male sterility in rice is due to epistatic interactions with a pollen killer locus. Genetics 189: 1083-1092.

Larser KD, Lersten NR. 1972. Anatomy and cytology of microsporogenesis in cytoplasmic male sterile angiosperms. Bot. Rev. 38: 425-454.

Lee DS, Chen LJ, Suh HS. 2005. Genetic characterization and fine mapping of a novel thermo-sensitive genic male- sterile gene tms6 in rice (Oryza sativa L.). Theor. Appl. Genet. 111: 271-277.

Levings III CS, Brown GG. 1989. Molecular biology of the plant mitochondria. Cell 56: 171-179.

Li J, Liang CY, Yang JL, Xing QH, Yang DE, Deng QY, Weng ML, Wang B. 2003. Cloning of the APRT gene from rice and analysis of its association with TGMS. Acta. Botanica. Sinica. 45: 1319-1328.

Li J, Yuan L. 2000. Hybrid rice: genetics, breeding, and seed production. Plant Breed. Rev. 17: 15-158.

Li H, Zhang D. 2010. Biosynthesis of anther cuticle and pollen exine in rice. Plant Signal. Behav. 5: 1121-1123.

Liang CY, Li J, Shu J, Deng QY, Guo BD, Wang B. 2004. Fertility alteration of male sterile rice line Annong S-1 and the expression of fertility related aprt gene. Acta. Genet. Sin. 31: 513-517.

Liechti R, Farmer EE. 2002. The jasmonate pathway. Science 296: 1649-50.

Liu XQ, Xu X, Tan YP, Li SQ, Hu J, Huang JY, Yang DC, Li YS, Zhu YG. 2004. Inheritance and molecular mapping of two fertility restoring loci for Honglian gametophytic cytoplasmic male sterility in rice (Oryza sativa L.). Mol. Gen. Genomics 271: 586-594.

Luo H, Lyznik LA, Gidoni D, Hodges TK. 2000. FLPmediated recombination for use in hybrid plant production. Plant J. 23: 423-430.
Lu X, Wang J. 1988. Fertility transformation and genetic behavior of Hubei photoperiod-sensitive genic male sterile rice. In: Hybrid rice. Los Baños (Philippines): IRRI pp.129-138.

Maruyama K, Araki H, Amano E, Kato H. 1990. Thermosensitive genetic male sterility induced by irradiation; in rice genetic II. Manila: IRRI pp.227-235.

Ma H. 2005. Molecular genetic analyses of microsporogenesis and microgametogenesis in flowering plants. Annu. Rev. Plant Biol. 56: 393-434.

MacMillan CP, Mansfield SD, Stachurski ZH, Evans R, Southerton SG. 2010. Fasciclin-like arabinogalactan proteins: specialization for stem biomechanics and cell wall architecture in Arabidopsis and Eucalyptus. Plant J. 62: 689-703.

Mariani C, De Beuckeleer M, Truettner J, Leemans J, Goldberg RB. 1990. Induction of male sterility in plants by a chimaeric ribonuclease gene. Nature 347: 737-741.

Mariani C, Gossele V, De Beuckeleer M, Block MD, Goldberg RB, Greef WD, Leemans J. 1992. A chimaeric ribonuclease-inhibitor gene restores fertility to male sterile plants. Nature 357: 384-387.

Martin JA, Crawford JH. 1951. Several types of sterility in Capsicum frutescens. Pro. Amer. Soc. Hort. Sci. 57: 335-338.

Matsui T, Omasa K, Horie T. 1999. Mechanism of anther dehiscence in rice (Oryza sativa L.). Annals Botany 84: 501-506.

Mei G, Wang X, Wang M. 1990. Genetical analysis of the photoperiod sensitive male sterity of Nongken $58 \mathrm{~S}$ and its derivative. J. HuaZhong Agric. Univ. 9: 400-406.

Moritoh S, Miki D, Akiyama M, Kawahara M, Izawa T, Maki H, Shimamoto K. 2005. RNAi-mediated silencing of OsGEN-L (OsGEN-like), a new member of the RAD2/XPG nuclease family, causes male sterility by defect of microspore development in rice. Plant Cell Physiol. 46: 699-715.

Nematzadeh G, Kiani G. 2010. Genetic analysis of fertility restoration genes for WA type cytoplasmic male sterility in Iranian restorer rice line DN-33-18. African J. Biotechnology 9: 6273-6277.

Newton KJ. 1988. Plant mitochondrial genomes: organization, expression and variation. Annu. Rev. Plant Physiol. Plant Mol. Biol. 39: 503-532.

Niemelä T, Seppänen M, Badakshi F, Rokka VM. 2012. Size and location of radish chromosome regions carrying the fertility restorer $\mathrm{Rfk} 1$ gene in spring turnip rape. 
Chromosome Res. 20: 353-361.

Nonomura K, Miyoshi K, Eiguchi M, Suzuki T, Miyao A, Hirochika H, Kurata N. 2003. The MSPl gene is necessary to restrict the number of cells entering into male and female sporogenesis and to initiate anther wall formation in rice. Plant Cell 15: 1728-1739.

Pedranzani H, Racagni G, Alemano S, Miersch O, Ramırez I, Pena-Cortes H, Taleisnik E, Machado-Domenech E, Abdala G. 2003. Salt tolerant tomato plants show increased levels of jasmonic acid. Plant Growth Regu. 141: 149-158.

Pedranzani H, Sierra-de-Grado R, Vigliocco A, Miersch O, Abdala G. 2007. Cold and water stresses produce changes in endogenous jasmonates in two populations of Pinus pinaster Ait. Plant Growth Regul. 52: 111-116.

Perez AT, Chang TT, Beachell HM, Vergara BS, Marciano AP. 1973. Induction of male sterility in rice with ethrel and RH-531. SABRAO Newsl. 5: 133-139.

Piston F, Garcia C, Vina ADL, Beltran P, Canas LA, Barro F. 2008. The pea PsEND1promoter drives the expression of GUS in transgenic wheat at the binucleate microspore stage and during pollen tube development. Mol. Breeding 21: 401-405.

Plackett ARZ, Thomas SG, Wilson ZA, Hedden P. 2011. Gibberellin control of stamen development: a fertile field. Trends Plant Sci. 16: 568-578.

Prasad K, Sriram P, Kumar CS, Kushalappa K, Vijayraghavan U. 2001. Ectopic expression of rice OsMADS1 reveals a role in specifying the lemma and palea, grass floral organs analogous to sepals. Dev. Genes Evol. 211: 281-290.

Qiao F, Yang Q, Wang CL, Fan YL, Wu XF, Zhao KJ. 2007. Modification of plant height via RNAi suppression of OsGA20ox2 gene in rice. Euphytica 158: 35-45.

Reddy OK, Siddiq EA, Sarma NP, Ali J, Hussain AJ, Nimmakayala P, Ramasamy P, Pammi S, Reddy AS. 2000. Genetic analysis of temperature-sensitive male sterility in rice. Theor. Appl. Genet. 100: 794-801.

Reflinur, Chin JH, Jang SM, Kim B, Lee JH, Koh HJ. 2012. QTLs for hybrid fertility and their association with female and male sterility in rice. Genes Genomics 34: 355-365.

Roque E, Gómez MD, Ellul P, Wallbraun M, Madueňo F, Beltrán JP, Caňas LA. 2007. The PsEND1 promoter: a novel tool to produce genetically engineered male-sterile plants by anther ablation. Plant Cell Rep. 26: 313-325.

Ruiz O, Daniell H. 2005. Engineering cytoplasmic male sterility via the chloroplast genome. Plant Physiology 138: 1232-1246.

Rutger JN, Schacffer GW. 1989. An environmentally sensitive genetic male sterile mutant in rice; in Agronomy abstracts pp.98, Annual meeting of the Amerian society of agronomists, Las Vegas, N.V.

Sakamoto T, Miura K, Itoh H, Tatsumi T, Tanaka MU, Ishiyama K, Kobayashi M, Agrawal GK, Takeda S, Abe K, Miyao A, Hirochika H, Kitano H, Ashikari M, Matsuoka M. 2004. An overview of gibberellin metabolism enzyme genes and their related mutants in rice. Plant Physiology 134: 1642-1653.

Sattari M, Kathiresan A, Gregorio G, Virmani SS. 2008. Comparative genetic analysis and molecular mapping of fertility restoration genes for WA Dissi, and Gambiaca cytoplasmic male sterility systems in rice. Euphytica 160: 305-315.

Sanders PM, Bui AQ, Weterings K, McIntire KN, Hsu YC, Lee PY, Truong MT, Beals TP, Goldberg RB. 1999. Anther developmental defects in Arabidopsis thaliana male-sterile mutants. Sex. Plant Reprod. 11: 297-322.

Sanders PM, Lee PY, Biesgen C, Boone JD, Beals TP, Weiler EW, Goldberg RB. 2000. The Arabidopsis DELAYED DEHISCENCE1 gene encodes an enzyme in the jasmonic acid synthesis pathway. Plant Cell 12: 1041-1061.

Sasaki A, Ashikari M, Tanaka MU, Itoh H, Nishimura A, Swapan D, Ishiyama K, Saito T, Kobayashi M, Khush GS, Kitano H, Matsuoka M. 2002. A mutant of gibberellin synthesis gene in rice. Nature 416: 701-702.

Shen Y, Gao M, Cai Q. 1994. A novel environmentinduced genic male sterile (EGMS) mutant in indica rice. Euphytica 76: 89-96.

Shi MS. 1985. The discovery and study of the photosensitive recessive male sterile rice (Oryza sativa L. Subsp. japonica). Scientia Agric. Sinica 2: 44-48.

Shi MS, Deng JY. 1986. The discovery, determination and utilization of Hubei photosensitive genic male sterile rice (Oryza sativa L. subsp. japonica). Acta Genet. Sin. 13: 107-112.

Shinjyo C, Sato S. 1994. Chromosomal location of a fertility restoration gene $R f 2$ in rice, Oryza sativa L. Rice Genet. Newsl. 11: 93-95.

Singh DP, Jermakow AM, Swain SM. 2002. Gibberellins are required for seed development and pollen tube growth in Arabidopsis. Plant Cell 14: 3133-3147.

Subudhi PK, Borkakati RP, Virmani SS, Huang N. 1997. 
Molecular mapping of a thermosensitive genetic male sterility gene in rice using bulked segregant analysis. Genome 40: 188-194.

Sun ZX, Cheng SH, Min SK, Xiong ZM, Yin CS, Si HM. 1991. Studies in response to photoperiod and temperature of the photoperiod sensitive genic male sterile rice (PGMSR) II Identification of Japonica PGMSR in growth chambers. Chinese J. Rice Sci. 5: 56-60.

Sun ZX, Xiong ZM, Min SK, Si HM. 1989. Identification of the temperature sensitive male sterile rice. Chinese J. Rice Sci. 3: 49-55.

Tan H, Liang W, Hu J, Zhang D. 2012. MTR1 encodes a secretory fasciclin glycoprotein required for male reproductive development in rice. Dev. Cell 22: 1127-1137.

Tanaka MU, Hirano K, Hasegawa Y, Kitano H, Matsuoka M. 2008. Release of the repressive activity of rice DELLA protein SLR1 by gibberellin does not require SLR1 degradation in the gid2 mutant. Plant Cell 20: 2437-2446.

Tang HV, Pring DR, Shaw LC, Salazar RA, Muza FR, Yan B, Schertz KF. 1996. Transcript processing internal to a mitochondrial open reading frame is correlated with fertility restoration in male-sterile sorghum. Plant J. 10: 123-133.

Tani T, Sobajima H, Okada K, Chujo T, Arimura S, Tsutsumi N, Nishimura M, Seto H, Nojiri H, Yamane H. 2008. Identification of the OsOPR7gene encoding 12-oxophytodienoate reductase involved in the biosynthesis of jasmonic acid in rice. Planta 227: 517-526.

Tsuchiya T, Toriyama K, Ejiri S, Hinata K. 1994. Molecular characterization of rice genes specifically expressed in the anther tapetum. Plant Mol. Biol. 26: 2737-1746.

Tsuchiya T, Toriyama K, Nasrallah ME, Ejiri S. 1992. Isolation of genes abundantly expressed in rice anthers at the microspore stage. Plant Mol. Biol. 20: 1189-1193.

Van de Meer IM, Stam ME, Van Tunen AJ, Mol JNM, Stuitje AR. 1992. Antisense inhibition of flavonoid biosynthesis in petunia anthers results in male sterility. Plant Cell 4: 253-262.

Virmani SS. 1992. Transfer and induction of thermosensitive genic male sterile mutant in Indica rice; in Pro. $2^{\text {nd }}$ Int. Symp. Hybrid rice, 21-25, Manila: IRRI.

Virmani SS. 1994. Heterosis and hybrid rice breeding. Berlin: Springer-Verlag. pp.189.

Virmani SS, Sun ZX, Mou TM, Jauhar Ali A, Mao CX. 2003. Two-line hybrid rice breeding manual, IRRI pp. 88 .
Von Malek B, Van der Graaff E, Schneitz K, Keller B. 2002. The Arabidopsis male-sterile mutant dde2-2 is defective in the ALLENE OXIDE SYNTHASE gene encoding one of the key enzymes of the jasmonic acid biosynthesis pathway. Planta 216: 187-192.

Wan BH, Deng YB. 1990. Observations on fertility changes in Hubei photoperiod sensitive genic male sterile rice Nongken 58S (Oryza sativa L. subsp. Japonica), J. South China Agric. Univ. 11: 1-6.

Wang X, Que RF. 1981. Induction of pollen sterility by ethylene and gametocides in rice. Acta Phytophysiol. Sin. 7: 381-383.

Wang B, Wang JZ, Wu W, Zheng HG, Yang ZY, Xu WW, Ray JP, Nguyen HT. 1995. Tagging and mapping the thermosensitive genic male sterile gene in rice (Oryza sativa L.) with molecular markers. Theor. Appl. Genet. 91: 1111-1114.

Wang Y, Wang YF, Zhang DB. 2006. Identification of the rice (Oryza sativa L.) mutant mspl-4 and expression analysis of its UDT1 and GAMYB genes. J. Plant Physiol. Mol. Biol. 32: 527-534.

Wang YG, Xing QH, Deng QY, Liang FS, Yuan LP, Weng ML, Wang B. 2003. Fine mapping of the rice thermo-sensitive genic male sterile gene tms5. Theor. Appl. Genet. 107: 917-921.

Wasternack C, Parthier B. 1997. Jasmonate-signalled plant gene expression. Trends Plant Sci. 2: 302-307.

Wei LQ, Xu WY, Deng ZY, Su Z, Xue Y, Wang T. 2010. Genome-scale analysis and comparison of gene expression profiles in developing and germinated pollen in Oryza sativa. BMC Genomics 11: 338.

Woo MO, Ham TH, Ji HS, Choi MS, Jiang W, Chu SH, Piao R, Chin JH, Kim JA, Park BS, Seo HS, NS Jwa, McCouch S, Koh HJ. 2008. Inactivation of the UGPase1 gene causes genic male sterility and endosperm chalkiness in rice (Oryza sativa L.). Plant J. 54: 190-204.

Worrall D, Hird DL, Hodge R, Paul W, Draper J, Scott R. 1992. Premature dissolution of the microsporocyte callose wall causes male sterility in transgenic tobacco. Plant Cell 4: 759-771.

Yamaguchi Y, Ikeda R, Hirasawa H, Minami M, Ujikara A. 1997. Linkage analysis of thermosensitive genic male sterility gene, tms 2 , in rice (Oryza sativa L.). Breed. Sci. 47: 371-373.

Yamaguchi T, Lee DY, Miyao A, Hirochika H, An G, Hirano HY. 2006. Functional diversification of the two C-class MADS box genes OsMADS3 and OsMADS58 
in Oryza sativa L. Plant Cell 18: 15-28.

Yang D, Wang NY. 1990. The breeding of themosensitive male sterile rice R 59TS. Scientia Agric. Sinica 23: 90.

Yang YH, Zhang FM, Ge S. 2009. Evolutionary rate patterns of the gibberellin pathway genes. BMC Evolutionary Biology 9: 206.

Yao FY, Xu CG, Yu SB, Li JX, Gao YJ, Li XH, Zhang Q. 1997. Mapping and genetic analysis of two fertility restorer loci in the wild-abortive cytoplasmic male sterility system of rice (Oryza sativa L.). Euphytica 98: 183-187.

Yoshida H, Nagato Y. 2011. Flower development in rice. J. Experimental Botany 62: 4719-4730.

Yuan LP. 1994. Increasing yield potential in rice by exploitation of heterosis. Pages 1-6 in Hybrid rice technology: New developments and future prospects, IRRI, Manila, Philippines.

$\mathrm{Xu}$ H, Knox RB, Taylor PE, Singh MB. 1995. Bcp1, a gene required for male fertility in Arabidopsis. Proc. Natl. Acad. Sci. USA 92: 2106-2110.

Zhang D, Liang W, Yin C, Zong J, Gu F, Zhang D. 2010. OsC6, encoding a lipid transfer protein, is required for postmeiotic anther development in rice. Plant Physiology 154: 49-62.

Zhang D, Wilson ZA. 2009. Stamen specification and anther development in rice. Chin. Sci. Bulletin 54:
2342-2353.

Zhang D, Xue L, Lu Z. 2011. Cytological analysis and genetic control of rice anther development. J. Genetics Genomics 38: 379-390.

Zhang G, Lu Y, Bharaj TS, Virmani SS, Huang N. 1997. Mapping of the $R f-3$ nuclear fertility-restoring gene for WA cytoplasmic male sterility in rice using RAPD and RFLP markers. Theor. Appl. Genet. 94: 27-33.

Zhang Q, Shen BZ, Dai XK, Mei MH, Saghai Maroof MA, Li ZB. 1994. Using bulked extremes and recessive class to map genes for photoperiod-sensitive genic male sterility in rice. Proc. Natl. Acad. Sci. USA 91: 8675-8679.

Zhao X, Palma J, Oane R, Gamuyao R, Luo M, Chaudhury A, Herve P, Xue Q, Bennett J. 2008. OsTDL1A binds to the LRR domain of rice receptor kinase MSP1, and is required to limit sporocyte numbers. Plant J. 54: 375-387.

Zhang ZG, Yuan SC, Xu CZ. 1987. The influence of photoperiod on the fertility changes of Hubei photoperiod sensitive genic male sterile rice (HPGMR). Chinese J. Rice Sci. 1: 137-143.

Zhang ZG, Yuan SC, Zen HL, Li YZ, Wang BX. 1991. Studies on the fertility changes of photoperiod-temperaturesensitive genic male sterile rice W6154s in response to temperature. J. Huazhong Agric. Univ. 10: 21-25. 